\title{
A Quantative Real-Time PCR of Phytophthora infestans in different Indian potato cultivars
}

\author{
Touseef Hussain $^{1}$, B.P.Singh ${ }^{2}$ and Firoz Anwar ${ }^{3}$, \\ ${ }^{1}$ Plant Pathology Lab., Central Potato Research Institute Campus,Modipuram-250110, Meerut,U.P \\ ${ }^{2}$ Central Potato Research Institute, Shimla-171001, H.P \\ ${ }^{3}$ Siddharatha Institute of Pharmacy, Uttarakhand Technical University, Dehradun, U.K
}

\begin{abstract}
Reliable and sensitive quantification of Phytophthorainfestansin potato plant is of crucial importance in managing the multiple syndromes caused by this pathogen. A Real-Time polymerase chain reaction (PCR) assay was developed for the determination of P.infestans in host tissues. DNA levels of a highly virulent isolate were measured in different potato cultivars with varying degrees of resistance. Using SYBR Green and specific primers for P.infestans the minimal amount of pathogen DNA quantified was $0.0005 \mathrm{ng} / \mu \mathrm{l}$. Pathogen DNA was recorded at 24 hours postinoculation. Thereafter, the increase was rapid in susceptible cultivars and slower in resistant ones. The amount of pathogen DNA quantified in each potato cultivars correlated with susceptibility to late blight. Likewise, there was a relationship between the virulence of the pathogen and the degree of colonization. Differences also were found in pathogen amount among host tissues, with maximal pathogen biomass occurring in susceptible one. The real-time PCR technique developed in this study was sensitive and robust enough to assess both pathogen development and resistance to Late blight in different potato genotypes.
\end{abstract}

Keywords: Phytophtohorainfestans, resistance, potato, cultivars, Real Time PCR

\section{Introduction}

Late blight (LB) is one of the most devastating diseases for potato worldwide, caused by Phytophthorainfestanswhich has re-emerged more aggressively because of the A2 mating type(Hooker 1983). This is particularly the case for the cultivated potato, where the organism is regarded as a threat to global food security.Its great yield potential, high nutritional value and its potential for industrial processing (e.g. bioethanol preparation) explain the ongoing global increase in potato production (Haverkort et al.2009).

This disease has been affecting potato crops since the nineteenth century, when it became known for causing the Irish Potato Famine (Fry and Mizubuti, 1998).

Potato is a host to many pathogens that affect all parts of the plant and case reductions in the quality and quantity in yield. This is due to the fact that new strain (A2) of P.infestans is resistant to the fungicide metalaxyl, and cultural control measures have limited effect in preventing and controlling the disease.The development of new cultivars that are more resistant to economically important pests and diseases is therefore one of the top priorities for potato breeding programme worldwide (Peters et al. 1999).The presence of both mating types allows sexual reproduction that contributes to the pathogen`s adaptation to certain fungicides and host resistance (Smart and Fry, 2001; Turkensteen et al. 2000). Mating also results in the formation of more resistant oospores that contributes to early infection. Rapid changes in the population of $P$. infestans are likely to require increased fungicide usage. The use of potato cultivars with durable host resistance could reduce fungicide applications, and therefore developing resistant cultivars is a focus for modern breeding programs (Inglis et al.1996; Peters et al.1999).Laboratory-based assays are based on samples ranging from whole plants to individuals tissues. Evolution has provided plant pathogens with a significant number of mechanisms to enhance their pathogenic potential and to ensure their survival. Likewise, plants have developed an equally diverse set of countermeasures to avoid their own demise. Throughout time, this co-evolution between host and pathogen has given form to what is defined today as plant-pathogen interactions (Peters et al. 1999; Pomar et al. 2001). Recently, the focus of this type of research has been partially shifted towards the exploration of the molecular basis of resistance, and ultimately to the improvement of the ability to genetically engineer durable resistance into commercial crops. Perhaps the first scientist to begin this exploration was H.H. Flor. who, in the 1940's, proposed the gene-for-gene model to explain the inheritance of plant disease resistance and pathogen virulence (Flor, 1971). Since then, a great deal of knowledge on the mechanisms controlling plant disease resistance has been accumulated. As India is a second largest developing economy in the world, in coming future and to feed up its billions of mouth, potato is going to play a major role in food security therefore late blight resistance varieties can play a very crucial role in healthy potato production.

Polymerase chain reaction (PCR) has been used for detection of a number of fungal plant pathogens based on the internal transcribed spacer (ITS) regions of ribosomal DNA (rDNA) (Henson and French, 1993). The $18 \mathrm{~S}, 5.8 \mathrm{~S}$, and $28 \mathrm{~S}$ nuclear rDNA genes are highly conserved for different fungal species and have been 
used for phylogenetic studies. Universal primers have been designed from these conserved regions for amplification of the ITS regions between the genes. The ITS regions evolve more quickly than the genes themselves and may vary among species within a genus (White et al. 1990), allowing the development of PCR primers that uniquely amplify a given species (Henson and French, 1993). High copy number of the rDNA genes increases sensitivity of this detection strategy so that rDNA can be amplified from a mixed- DNA preparation (White et al. 1990). Fungal DNA can be detected from a DNA extraction of diseased plant tissue when using primers that amplify the rDNA regions (Henson and French, 1993) and among the PCR-based methods, real-time PCR has proven to be a simple yet reliable technique to quantify viral, bacterial, fungal, and oomycete plant pathogens, and increasingly is being used in plant pathology (Bohm et al.,1999;MaCartney et al.2003; Mumford et al.2000; Schaad et al.2003;Vandemark and Barker et al.2003). In this technique, the DNA of a specific target organism can be quantified by measurement of the intensity of fluorescence with time during the exponential phase of DNA amplification. Quantification of DNA in unknown samples will be possible by direct comparison with standards amplified in parallel reactions (Moorison et al.1998). The main advantage of this technique compared with the conventional one, end-point quantitative PCR, is that the amplification products can be monitored as they are accumulated in the log-linear phase of amplification. Therefore, it is more accurate, less time-consuming, and better suited, especially when the objective is to discriminate between slightly different levels of infection (Winton et al.2003).

A number of biochemical assays have been developed to quantify pathogen levels in host plant tissue. A main advantage of these assays is that they can confirm the presence of the pathogen, in susceptible, intermediate and resistant plants. Consequently, they can distinguish between susceptible and resistant cultivars. The development of a real-time approach enabled the quantification of pathogen biomass in plants over the course of infection. This method will facilitate the characterization of host-pathogen interactions. The aims of the present work were to (i) develop a real-time PCR assay to quantify P.infestansbiomass in potato plants and (ii) monitor pathogen growth in potato plants in relation to different host susceptibility.

\subsection{Pathogen material}

\section{Materials And Methods}

Recent works was carried out in our laboratory (CPRIC, Modipuram), a population of IndianP.infestansisolates was characterized accordingto their virulence. One highly virulent (HP-IS389) was selected for this work. The isolate wasmaintained on RyeA agar medium for further use. To obtain mycelium, theisolates were grown in pea broth (Cooke et al. 2000). After 1 week of incubation at $14^{\circ} \mathrm{C}$, mycelium was collected and lyophilizedfor extended storage.

\subsection{Plant material}

Six different cultivars of potato cultivars wereused: Susceptible cv. K.Bahar, K,Surya, moderate resistance cv. K.Phukhraj, K.Anand and Resistance cv.K.Girdhari, K.Megha,each with different levels of resistance to P.infestansbeing the most resistant. Moreover, a susceptible local cultivar(K.Bahar) was included because of its economic value in north-westernIndia region. Plants were transferred into pots and grown separatelyin a chamber at $20^{\circ} \mathrm{C}$ and a photoperiod of $16 \mathrm{~h}$ of light and $8 \mathrm{~h}$ of darkness until they were 40 days old.

\subsection{Detached leaf method /Pathogen Inoculation}

Six potato plant leaflet each of cultivarsviz., K.Bahar, K.Surya, K.Phukraj, K.Anand, K.Girdhari and K.Megha, were raised in $20 \mathrm{~cm}$ earthen pots under the glass house. On the 40thday of planting, the terminal leaflet of the fourth leaf from the top was used in the study. Five leaflets collected from each cultivar were placed in plastic trays on perforated plastic separators (Umaerus and Lihnell, 1976) and inoculated with $50 \mu 1$ zoosporangial suspension containing $6 \times 10^{4}$ zoospores $/ \mathrm{ml}$ using an autopipette. Trays containing the inoculated leaflets were incubated in an incubator at $18 \pm 1^{\circ} \mathrm{C}$. Lesion size (length and width) was measured after every $24 \mathrm{~h}$ inoculation and the lesion area was calculated by using the following formula (Singh and Bhattacharyya, 1995).

Area $=\pi \mathrm{ab} / 4$

where $\mathrm{a}$ and $\mathrm{b}$ are the length and width of the lesion, respectively.Lesion area was measured for 5 days of incubation and calculated as standard procedures.

\subsection{DNA extraction}

Mycelia of P.infestans isolates were obtained by growth in pea broth (120g frozen peas per litre sterile distilled water) at $18{ }^{\circ} \mathrm{C}$ for at least 2 week. Mycelia were harvested by filtration and frozen at $-20^{\circ} \mathrm{C}$. DNA was extracted from mycelia according to a modification (Murry and Thompson 1980) of the Cetyltrimethylammonium bromide procedure (CTAB). Frozen mycelil grounded to powder, placed in sterile 
Ookargide tubes containing pre-warmed extraction buffer and beta mercaptoethanol incubate tubes at $65^{\circ} \mathrm{C}$ for an hour, with occasional stirring. Add equal volume of Chloroform: Isoamyl alcohol (24:1 v/v), mixed gently. Centrifuged at 10,000 rpm for 10 minsUpperaquespahse transferred into fresh tubes followed by adding 0.6 vol of ice cold Isopropanol, incubate at $-20^{\circ} \mathrm{C}$ for overnight. Centrifuged at $12000 \mathrm{rpm}$ for $10 \mathrm{~min}$ at $4^{\circ} \mathrm{C}$.DNA pellets were separated from supernatants. Pellets washed twice with $70 \%$ ethanol, recenrtifuged at $10000 \mathrm{rpm}$ for $10 \mathrm{~min}$ then dried at room temperature until smell of ethanol is removed from the tubes. Pellets were dissolved in T.E buffer and stored at $-20^{\circ} \mathrm{C}$ in small aliquots. Isolated DNA was purified by using $1 \mu 1$ RNAs A $(5 \mu \mathrm{g} / \mathrm{ml})$. DNA yield and purity was determined by spectrophotometer (Nanodrop).

2.5 Real-time PCR assay

Real-time PCR assays for quantificationof pathogen in different cultivars were conducted using primerpair Taq1/Taq2 (Hussainet al. 2005), which defines an amplicon of 103bpspecific for P.infestans. Realtime PCR was performed in anABI SteponePlus ${ }^{\mathrm{TM}}$ Real Time PCR System (USA) apparatus and results were analysed with the manufacturer's software (SDS Software,Ver. 2.2,ABI). Each reaction mixture $(25 \mu \mathrm{l})$ contained $2.5 \mu \mathrm{l}$ ofundiluted DNA extract, $2 \mathrm{X}$ Ready to use SYBR GreenMasterMix (ABI), and $0.3 \mu \mathrm{M}$ of each primer and sterile distilled water for volume makeup. In negative controls, the DNA extractswere obtained from non-inoculated plants of the same age andsame culture conditions as inoculated ones. Additional negativecontrol reactions contained the same mixtures with $2.5 \mu \mathrm{l}$ ofsterile water replacing the DNA. The thermal cycling conditionsconsisted of an initial denaturation at $95^{\circ} \mathrm{C}$ for 10 min followed by 40 cycles at $95^{\circ} \mathrm{C}$ for $15 \mathrm{~s}, 60^{\circ} \mathrm{C}$ for $1 \mathrm{~min}$. Fluorescence of the target amplicon (melting temperature $(\mathrm{Tm})=81.5^{\circ} \mathrm{C}$ ) was detected at $84^{\circ} \mathrm{C}$. After the final amplification cycle, a melting curve temperature profile was obtained by heating to $95^{\circ} \mathrm{C}$, cooling to $60^{\circ} \mathrm{C}$, and slowly heating to $95^{\circ} \mathrm{C}$ at $0.5^{\circ} \mathrm{C}$ every $15 \mathrm{~s}$ with continuous measurement of fluorescence at $520 \mathrm{~nm}$. Astandard curve was constructed by plotting the logarithm of 10 -fold serial dilutions from $5 \mathrm{ng} / \mu 1$ to $0.0005 \mathrm{ng} / \mu \mathrm{l}$ of P.infestansDNAagainst the cycle threshold $(\mathrm{Ct})$ values (Fig. 4). The $\mathrm{Ct}$ value is the cyclenumber at which the fluorescence emission of the PCR ampliconcould be distinguished from the background. When constructing a regression line withthese data, a linear relationship was observed, as happened in thestandard curve (data not shown). The amount of pathogen DNA in unknown samples was calculatedby monitoring the $\mathrm{Ct}$ value at which the fluorescenceemission could be differentiated from the background and comparingthis $\mathrm{Ct}$ value with the point values of the linear regressionline of the standard curve.

\subsection{Statistical analyses}

Statistical analyses were performed usingStatgraphics Plus for Windows, 5.1 Professional Version (StatPoint,Inc., Herndon, VA). Data of pathogen DNA quantification amongcultivars were analyzed using the Kruskal-Wallis test $(P \leq 0.05)$ followed by the multiple comparison procedure of Conover $(1980)$.

\subsection{Disease assessment in different potato cultivars}

\section{Results}

The capacity of the P.infestansisolates to infect potato plants was tested in a group of six potato cultivars, differing in their degree of susceptibility to the pathogen. Data on disease severity were plotted over time to obtain disease progress curves (Fig. 1). In general, differences could be observed among cultivars, isolates, and cultivar-isolate interactions. Susceptible cv.K.Bahar and K.Surya showed high disease severity with P.infestansisolates.Detached leaf revealed the first visible symptoms on the $24 \mathrm{hrs}$ interval after inoculation, although the disease progress over time was higher in plants inoculated with HP-IS389(Fig.2).In the first case, a maximal infection (severity index $=4.8$ ) was reached at $6^{\text {th }}$ day after infection.In the K. Megha and K.GirdhariHP-IS289 interaction, however, disease progression was slowerand the severity rating achieved at the end of the ongoing period was only 1.5, with only $10 \%$ diseased plants (data not shown). After inoculation with HP-IS389, the infection pattern displayed by intermediate cv.K.Phukhraj and K. Anand was similar to that in susceptible one, but showed the highest degree of susceptibility (severity rate $=5$ and percentage of infected plants $=100 \%$ ) However, after inoculation with HP-IS389, the severity achieved by K. Girdhari was higher than in K. Megha. In contrast, resistant genotypes showed the lowest diseaseseverity. No disease symptoms were observed when the detached leafwere infected with HP-IS389, and slower progress curves were obtained in K. Girdhri and K. Megha -HP-IS389 system compared with those in susceptible cultivars. In the last case, more symptoms developed in K.Girdhari than in K.Megha, with 40 and $20 \%$ disease percentage (data not shown) and 2 and 1 severity index, respectively, at the end of the trials. Noninoculated plantsdid not show any symptoms (data not shown). P.infestanswas detected successfully from leaves in four potato genotypes (K. Bahar, K.Surya, K.Phurkraj and K. Anand inoculated with isolates at 24 after inoculation but not in resistance one (K. Girdhari and K. Mehga)(Fig. 3). 


\subsection{Real-time PCR adjustment and DNA standard curves}

Additionally, to confirm the presence of the single expected amplicon of $103 \mathrm{bp}$, final products of realtime PCR from both standard curve and unknown samples were visualized in agarose gels (data shown). A standard curve was constructed by plotting known concentrationsof P.infestansDNA against the $\mathrm{Ct}$ values obtained fromreal-time PCR (Fig.4). In order to validate the reproducibility ofthe real-time PCR method, PCR amplifications were conductedwith triplicate samples of pathogen DNA. Highly reproducible $\mathrm{Ct}$ values with verysmall standard deviations were observed, the linear regression coefficientof the standard curve being $R=$ 0.952. Within this standardcurve, each 10-fold difference in initial DNA amounts wasrepresented by approximately four-cycle differences in $\mathrm{Ct}$. underthe PCR conditions tested, the minimum starting quantity of pathogen DNA that could be accurately quantified in our assayswas $5 \mathrm{ng}$, which corresponded to a $\mathrm{Ct}$ value of $20 \pm 1.06$. ACt of 21 was considered to be the threshold value suitable for quantification,because PCR efficiency at a higher number of cycles wasfar from the value 1 (98\% efficiency) (Fig. 9).

\subsection{Quantification of P.infestansDNA in potato genotypes leaves}

PathogenDNA was quantified in detached leaf using real-time PCR with Ready to use 2xSYBRGreen Dye (ABI,USA) before first symptoms of the disease were observed in plants(Fig. 5). Indeed, symptoms did not appear in infected plants until 3 days after inoculation in resistance cultivars, however, with thereal-time PCR assay, pathogen DNA could be quantified at $24 \mathrm{hr}$ postinoculation (Fig.6). From that time point, the pathogen DNA increased progressivelyuntil the end of the bioassay. Real-time PCR quantificationshowed important differences among the different potato genotypes. In general, susceptible were more heavily colonized than intermediate, and then resistance leaves. In all cases, the maximal amount of pathogen DNA occurred at $72 \mathrm{hr}$ after inoculation (Fig. 7). Although the pathogen was able to colonize all the susceptible and intermediate potato cultivars evaluated, the extent of colonization varied highly among cultivars with different levels of resistance. In most of the cases, higher amounts of pathogen DNA were present at $72 \mathrm{hr}$ after inoculation in susceptible cultivars (K. Bahar and K. Surya) than in the more resistant ones (K. Girdhari and K. Megha) (Fig. $7)$. In the susceptible cultivars, pathogen DNA was detected earlierpossible at $24 \mathrm{~h}$ and increased sharply over time whereas, in the resistant plants, the variations in pathogen development were slighter. $\operatorname{Significant}(P \leq 0.05)$ differences were found among resistant and susceptiblecultivars at 24 hrpost inoculation in the leaf (Fig.6) although, at $48 \mathrm{hr}$, there was nosignificant differences. The differences were significant at 72 hrpost inoculation in all the leaves. Comparingthe cultivars separately, susceptible cv.K.Bahar and K.Surya,K.Phukhraj, K.Ananddisplayed a similar pattern of pathogen invasion, butsignificant differences between them were found in the leaves of resistance cultivars at 48and 72 hrpost inoculation(Fig.7). For the resistant cultivars,significantdifferences were found in K.Girdhari comparedwith the partially resistant K.Phukhraj and K.Anand only in the case of leaves at $48 \mathrm{hr}$ post inoculation (Fig. 8). In any case, the accumulation of pathogen DNA in these resistant genotypes was slowerthan that in susceptible and intermediate cultivars and the amount of pathogenDNA generally remained lower during the study.With regard to the single P.infestansisolate, a different pattern of infection was observed. Up to $0.79 \mathrm{ng} / \mu \mathrm{l}$ and $0.16 \mathrm{ng} / \mu \mathrm{l}$ of pathogen DNAwas observed at 24hrpost inoculation in the K.Bahar and K.Surya interactions (Fig.3). In the same way,the average pathogen DNA inthe moderateresistant cultivar system was $0.33 \mathrm{ng} / \mu \mathrm{l}$ and $0.57 \mathrm{ng} / \mu \mathrm{l}$, whereas it could not be detected inK.Girdhari or in K.Megha until $24 \mathrm{~h}$ after infection, when the plantswere inoculated with the pathogen.These results correspond with those obtained in the severity assessment assay, where clear differences between isolates also were observed.

\section{Discussion}

One of the objectives of this study was the development of an accurate quantification method of pathogen colonization in host tissue using real-time PCR technology and the use of this method for a better understanding of the interaction between different potato genotypes and P.infestansisolate. With this purpose, six different potato cultivars were artificially infected with aP.infestansisolate.Pathogen DNA was monitored and quantified in a time course after inoculation using a quantitative SYBR Green PCR assay. In recent years, real-time PCR assays have been widely used for the detection and quantification of fungal plant pathogens (Bates et al. 2001; Filion et al. 2003; Schenaet al. 2004). Similar studies have been carried out in Phytophthoraspp. (Bohmet al. 1999; Bonants et al. 2004;Hayden et al. 2004; Ippolito et al. 2004; Vandemark et al. 2003). However, to the best of our knowledge, no attempts had been made to apply the real-time PCR technology for quantification of P.infestansin potato cultivars in Asian region. In our study, the results showed that real-time PCR can besuccessfully implemented for the quantification of potato colonization by P.infestans. The technique was highly reproducible, the correlation coefficient of the standard curve constructed with different replications being 0.952 . At the same time, the method was quite sensitive, being able to readily detect, using the unspecific SYBR Green dye and specific primers to P.infestans, up to $0.0005 \mathrm{ng} / \mu 1$ of pathogen DNA. Similar quantification limits have been found in other pathogen-plant interactions (Filion et al. 2003; Gachon et 
al. 2004) as well as in other Phytophthoraspp., although using different real-timechemistries (Ippolito et al. 2004). The Ct values depend on both the amount of starting DNA and the genomic organization of the target sequences recognized by the sequence-specific primer pair; therefore, the efficiency of the technique will improve if the target DNA is present in many copies in the genome, as is the case with rDNA. This sensitivity was similar to that achieved in previous works using conventional PCR but less than that obtained with anested PCR assay (Silver et al. 2005). These results agree with those publishedrecently by Bonants et al. (2004) working on $P$. fragariae. They obtained similar kind of detection limits by using either conventional PCR or a TaqMan assay but higher sensitivity with a nested PCR. In any case, with this sensitivity, pathogen abundance can be reliablyquantified from the very beginning of the infection time course and even in tissues exhibiting a low degree of infection. In a parallel assay, the influence of plant samples on quantification was tested (data not shown).In a real-time PCR assay, the accumulation of the amplicon canbe detected using either specific detection methods such as TaqMan probes (Holland et al. 1991; Tyagi et al. 1996; Whitecombeet al. 1999) or nonspecific methods like SYBR Green (Morrison et al. 1998). The advantage of SYBR Green is that, in contrast to fluorogenic probes, it does not require the design of specific complementary fragments to the target DNA and, therefore, the reaction cost is limited compared with real-time PCRs that depend on hybridization of labelled sequence-specific probes. The main disadvantage of this method is that it binds double-stranded DNA and, therefore, it also can associate with primer-dimers and nonspecific products, which can seriously disturb the interpretation of the results. However, this major drawback can be overcome with the use of melting curve temperature analysis at the end of the PCR assay (Ririe et al. 1997). At the end of the cycling reactions, the products are melted by slowly increasing the temperature while continually monitoring the fluorescence. After melting curve analysis in our assay, the use of unspecific SYBR Green dye for quantifying thetarget amplicon $\left(\approx 103 \mathrm{bp}, \mathrm{Tm}=86.5^{\circ} \mathrm{C}\right)$ required a $84^{\circ} \mathrm{C}$ fluorescenceemission reading step in the amplification program to eliminate any interference caused by the accumulation of unspecific PCR products. At that temperature, the nonspecific products will be denatured and only the fluorogenic emission from the target amplicon would result. One of the results in this work is that the real-time PCR methoddeveloped here is able to quantify pathogen invasion in the absence of visible host plant symptoms. Although the first visible symptoms appeared in detached leaf within $24 \mathrm{hr}$ after infection, quantification was possible at earlier times (at 24hrpost inoculation) in totally asymptomatic plants. Thereafter, the amount of pathogen DNA either increased sharply or varied more slightly during the study period, but in no case were the symptoms observed in inoculated detached leaves. It must be pointed out that P.infestansis detected in leaves at $24 \mathrm{hrpost}$ inoculation. It is surprising that thepathogen can invade and colonize the host so fast. This fact probably is due to the pathogen's ability to move through the vascular system and the small size of the plants at the time of the experiments. It was also an unexpected result that the pathogen was not isolated at $24 \mathrm{hr}$ after inoculation, taking into account that pathogen DNA was detected at that time. Maybe nonviable pathogen cells were present at that time. Another possibility is that the pathogencolonized only the outer layers of cells at that time, after which surface sterilization could have killed the pathogen.

The amount of pathogen DNA quantified $72 \mathrm{hr}$ after inoculation in each potato genotype correlated with the level of susceptibility or resistance to disease caused by P.infestans (as indicated by severity of symptoms). Maximal absolute amounts of pathogen DNA were quantified in susceptible genotypes K.Bahar and K.Surya (the most severely diseased genotypes), where measurements in leaves ranged from $0.79 \mathrm{ng} / \mathrm{ul}$ in K.Bahar to $0.16 \mathrm{ng} / \mathrm{ul}$ in K.Surya. Actual amounts of P.infestansDNA varied considerably for a given potato genotype-P.infestansisolate interaction and, in some cases, between P.infestansisolates for a given potato genotype. In the same way, smaller amounts of pathogen DNA were quantified in K.Girdhari and K.Megha plants, in that order. These two cultivars also produced fewer diseased plants or even none at all. Therefore, reduced disease severity in those cultivars considered resistant corresponded to the results of the quantitative analysis of pathogen DNA. In recent years, several different studies have demonstrated the utility of real-time PCR to discriminate between plant genotypes displaying different levels of resistance (Brouweret al.2003;Gachonet al.2004;Mercado-Blanco et al.2003;Qi and Yang,2002;Zhou et al.2004). Vandemark and Barker (2003), studying the P. medicaginis - alfalfa interaction, were able to discriminate among three alfalfa populations with different levels of resistance. They also detected less pathogen DNA in highly resistant alfalfa populations than in more susceptible ones. Moreover, the results of our work corroborate others published previously which established clear differences in resistance among K.Girdhari and K.Megha (resistant cultivars) and K.Bahar, K.Surya (susceptible genotype) (Black et al.1998;Gil Ortega et al.1991,1995). The difference with the present work is that previous classifications of potato susceptible or resistant to Late Blight of potatowere based on the evaluation of external symptoms and measurement of incidence and severity of plant symptoms, which is time consuming and sometimes inconclusive. In terms of pathogen ability to infect the plant, it seemed clear that the more virulent isolate had a better capacity not only to infect the plant sooner but also to spread quicker during the time course of infection. In general, the average amount of pathogen DNA was higher for HP-IS389 infected leaf. Moreover, the accumulation of pathogen DNA was rapid in susceptible 
genotype-most virulent isolate interactions whereas, in less compatible interactions, it was more progressive and notable increases in pathogen amount did not take place, the quantity of pathogen DNA being more constant over time. Considering all these results, the difference in virulence of the P.infestansisolates could be attributed to differences in pathogen amount in infected plants, among other factors. However, a clear correlation between the virulence of a pathogen and the amount of pathogen present in the plant does not always exist. Sometimes, more virulent isolates do not involve an increase in pathogen colonization (Mercado-Blanco et al.2003; Thommaet al.1999). Another interesting aspect was the different amounts of pathogen DNA in the different tissues collected. Comparatively, the amount of pathogen DNA in leaves was much lower than that quantified. This tissue difference suggests either a temporal sequence of systemic colonization by the pathogen or a differential response of the plant defence mechanisms. Differences in the level of colonization of different tissues by the pathogen have been reported in other plant-pathogen interactions (Mercado-Blanco et al. 2003;Zhou et al.2004). It has been reported that some plant defence-related genes, which encode pathogenesisrelated proteins, display a differential expression in various potato organs in response to pathogen infection (Jung et al.2000;Jung et al.2003; Shin et al.2001). Such responses could be responsible for that differential distribution, preventing pathogen advance, especially in the cultivars that are more resistant.

\section{Conclusion}

A final conclusion of the present work was that the local potatocv.K.Bahar displayed an infection and quantification pattern similar to that in K.Surya,K.Phurkraj,K.Anand suggesting that it may have a similar degree of susceptibility. K. Bahar is a potato cultivar of high economic importance in north-western, India and widely famous, preferred among farmers. The results in this study have demonstrated its level of susceptibility to Late Blight of potato, the most important disease of potato crops in this region. The real-time PCR developed here, together with disease severity studies, will enable the selection of the most resistant plants within the K.Bahar cultivar for disease resistance breeding in the future.

\section{Acknowledgements}

Author is thankful to PHYTOFURA Project and ICAR-New Delhi for funding our research study.

\section{References}

[1] Hooker, W.J, Late blight. In: WJ Hooker ed. compendium of potato disease(APS Press. St. Paul, MN, USA, 1983) 40-42.

[2] Haverkort, A., Struik, P., Visser, R., Jacobsen, E, Applied biotechnology to combat late blight in potato caused by Phytophthorainfestans. Potato Res.52,2009,249-264.

[3] Fry WE, and ES Mizubuti,potato late blight. (In: DG Jones ed. The epidemiology of plant diseases. Kluwer Academic Publishers, Boston, Ma USA,1998,371-388.)

[4] Peters, R.D., Platt, H.W., Hall, R., Medina, M,Variation in aggressiveness of Canadian isolates of Phytophthorainfestans as indicated by their relative abilities to cause potato tuber rot. Plant Dis. 83,1999,652-661.

[5] Smart, C. D., Mayton, H., Mizubuti, E. S. G., Willmann, M. R., and Fry, W. E,Environmental and genetic factors influencing selffertility in Phytophthorainfestans. Phytopathology. 90,2001, 987-994.

[6] Turkensteen, L.J., Flier, W.G., Wanningen, R and Mulder, A,Production, survival and infectivity of oospores of Phytophthorainfestans. Plant Pathology. 49,2000, 688-696.

[7] Inglis, D.A., Johnson, D.A., Legard, D.E., Fry, W.E., and Hamm, P.B, Relative resistances of potato clones in response to new and old populations of Phytophthorainfestans. Plant Dis. 80,1996,575-578.

[8] Pomar, F., Bernal, M. A., Collar, J., Díaz, J., Caramelo, C., Gayoso, C., Novo, M., Prego, C., Saavedra, A., Silvar, C., and Merino, F,A survey of "Tristeza" of pepper in Galicia and the fungal pathogens causing the disease. Capsicum Eggplant Newsl. 20,2001,9093.

[9] Flor, H.H, Current status of the gene-for-gene concept. Annu. Rev. Phytopathol,9,1971, 275-296.

[10] Henson, J. M., and French, R, The polymerase chain reaction and plant disease diagnosis. Annu. Rev. Phytopathol. 31,1993,81-109.

[11] White, T. J., Bruns, T., Lee, S., and Taylor, J, amplification and direct sequencing of fungal ribosomal rna genes for phylogenetics. Pages 315-322 in: (PCR Protocols: A Guide to Methods and Applications. M. A. Innis, D. H. Gelfand, J. J. Sninsky, and T. J. White, eds. Academic Press, San Diego, CA,1990)

[12] Böhm, J., Hahn, A., Schubert, R., Bahnweg, G., Adler, N., Nechwatal, J., Oehlmann, R., and Obwald, W, Real-time quantitative PCR: DNA determination in isolated spores of the mycorrhizmosseaeand monitoring of Phytophthorainfestansand Phytophthoracitricolain their respective host plants. J. Phytopathol.147,1999,409-416.

[13] McCartney, H. A., Foster, S. J., Fraaije, B. A., and Ward, E, Molecular diagnostics for fungal plant pathogens. Pest. Manage. Sci. 59,2003,129-142.

[14] Mumford, R. A., Walsh, K., Barker, I., and Boonham, N,Detection of potato mop top virus and tobacco rattle virus using a multiplex real time fluorescent reverse-transcription polymerase chain reaction assay. Phytopathology. 90, 2000, 448-453.

[15] Schaad, N. W., Frederick, R. D., Shalev, A., Shaw, J., Schneider, W. L., Hickson, R., Petrillo, M. D., and Luster, D. G, Advances in molecular-based diagnostics in meeting crop biosecurity and phytosanitary issues. Annu. Rev. Phytopathol. 41,2003,305-324.

[16] Vandemark, G. J., and Barker, B. M, Quantifying Phytophthoramedicaginisin susceptible and resistant alfalfa with a real-time fluorescentassay. J. Phytopathol. 151,2003, 577-583.

[17] Morrison, T. B., Weis, J. J., and Wittwer, C. T, Quantification of low-copy transcripts by continuous SYBR Green I monitoring during amplification. BioTechniques. 24, 1998, 954-962.

[18] Winton, L. M., Manter, D. K., Stone, J. K., and Hansen, E. A,Comparison of biochemical, molecular, and visual methods to quantify Phaeocryptopusgaeumanniiin Douglas-Fir foliage. Phytopathology. 93,2003, 121-126.

[19] Cooke, D. E. L., Drenth, A., Duncan, J. M., Wagels, G., and Brasier, C. M, A molecular phylogeny of Phytophthoraand related Oomycetes. Fungal Genet.Biol. 30,2000, 17-32. 
[20] Umaerus, V. and Lihnell, D,A laboratory method for measuring the degree of attack of Phytophthorainfestans. Potato Research. 19,1976,91-107.

[21] Singh, B.P. and Bhattacharyya, S.K, Field resistance to late blight in four Indian potato cultivars. Potato Research, 38,1995,171178 .

[22] Murray, M.G. and Thompson, W.F, Carnegie Inst. Wash. Year Book ,1977, 76:255-259.

[23] Hussain, S., Lees, A.K., Duncan, J.M. and Cooke, D.E.L,Development of a species-specific and sensitive detection assay for Phytophthorainfestans and its application for monitoring of inoculum in tubers and soil. Plant Pathol., 54,2005,373-382.

[24] Conover, W. J,Practical Nonparametric Statistics. (John Wiley \& Sons, Inc., New York, 1980)

[25] Bates, J. A., Taylor, E. J. A., Kenyon, D. M., and Thomas, J. E, The application of real-time PCR to the identification, detection and quantification of Pyrenophoraspecies in barley seed. Mol. Plant Pathol. 2,2001, 49-57.

[26] Filion, M., St-Arnaud, M., and Jabaji-Hare, S. H, Direct quantification of fungal DNA from soil substrate using real-time PCR. J. Microbiol. Methods.53,2003,67-76.

[27] Schena, L., Nigro, F., Ippolito, A., and Gallitelli, D, Real-time quantitative PCR: A new technology to detect and study phytopathogenic and antagonistic fungi. Eur. J. Plant Pathol. 110,2004,893-908.

[28] Bonants, P. J. M., van Gent-Pelzer, M. P. E., Hoofman, R., Cooke, D. E. L., Guy, D. C., and Duncan, J. M, A combination of baiting and different PCR formats, including measurement of real-time quantitative fluorescence, for the detection of Phytophthorafragariaein strawberry plants. Eur. J. Plant Pathol.110,2004,689-702.

[29] Hayden, K. J., Rizzo, D., Tse, J., and Garbelotto, M, Detection and quantification of Phytophthoraramorumfrom California forests using a real-time polymerase chain reaction assay. Phytopathology.94,2004,1075-1083.

[30] Filion, M., St.-Arnaud, M., and Jabaji-Hare, S. H, Quantification of Fusariumsolanif. sp. phaseoliinmycorrhizal bean plants and surrounding mycorrhizosphere soil using real-time polymerase chain reaction and direct isolations on selective media. Phytopathology, 93,2003,229-235.

[31] Gachon, C., and Saindrenan, P. (2004): Real-time PCR monitoring of fungal development in Arabidopsis thaliana infected by Alternariabrassicicolaand Botrytis cinerea. Plant Physiol. Biochem. 42,2004, 367-371.

[32] Ippolito, A., Schena, L., and Nigro, F., Ligorio, V. S., and Yaseen, T, Real-time detection of PhytophthoranicotianaeandP. citrophthorain citrus roots and soil. Eur. J. Plant Pathol. 110,2004,833-843.

[33] Silvar, C., Duncan, J. M., Cooke, D. E. L., Williams, N. A., Díaz, J., and Merino, F, Development of specific PCR primers for identification and detection of PhytophthoracapsiciLeon. Eur. J. Plant Pathol.112,2005,43- 52.

[34] Holland, P. M., Abramson, R. D., Watson, R., and Gelfand, D. H, Detection of specific polymerase chain reaction product by utilizing the 5'-3'exonuclease activity of ThermusaquaticusDNA polymerase. Proc. Natl. Acad. Sci. USA. 88,1991,7276-7280.

[35] Tyagi, S., and Kramer, F. R, Molecular beacons: Probes that fluoresce upon hybridization. Nat. Biotechnol. 14,1996, 303-308.

[36] Whitcombe, D., Theaker, J., Guy, S. P., Brown, T., and Little, S. (1999): Detection of PCR products using self-probing amplicons and fluorescence. Nat.Biotechnol. 17,1999,804-807.

[37] Ririe, K. M., Rasmussen, R. P., and Wittwer, C. T Product differentiation by analysis of DNA melting curves during the polymerase chain reaction. Anal.Biochem.245,1997,154-160.

[38] Brouwer, M., Lievens, B., van Hemelrijck, W., van den Ackerveken, G., Cammue, B. P. A., and Thomma, B. P. H. J, Quantification of disease progression of several microbial pathogens on Arabidopsisthaliana using real-time fluorescence PCR. FEMS Microbiol. Lett.228, 2003, 241-248.

[39] Mercado-Blanco, J., Collado-Romero, M., Parrilla-Araujo, S., Rodríguez- Jurado, D., and Jiménez-Díaz, R. M, Quantitative monitoring of colonization of olive genotypes by Verticillium dahlia pathotypes with real-time polymerase chain reaction. Physiol. Mol. Plant Pathol.63, 2003, 91- 105.

[40] Qi, M., and Yang, Y, Quantification of Magnaporthegriseaduring infection of rice plants using real-time polymerase chain reaction and northern blot/phosphimaging analyses. Phytopathology. 92,2002, 870-876.

[41] Zhou, X. G., and Everts, K. L, Quantification of root and stem colonization of watermelon by Fusariumoxysporumf. sp. niveumand its use in evaluating resistance. Phytopathology. 94, 2004,832-841.

[42] Black, L. L., and Berke, T. (1998):Breeding for Phytophthora resistance in pepper. XthEucarpia Meeting on Genetics and Breeding of Capsicum and Eggplant. Avignon, France, 1998.

[43] Gil Ortega, R., Español, C. P., and Zueco, J. C, Genetics of resistance to Phytophthoracapsiciin the pepper line "SCM-334". Plant Breed. 107, 1991,50-55.

[44] Gil Ortega, R., Español, C. P., and Zueco, J. C, Interactions in the pepper-Phytophthoracapsicisystem.Plant Breed.114, 1995,74-77.

[45] Thomma, B. P. H. J., Tadesse, Y. S. H., Jacobs, M., and Browkaert, W. F, Disturbed correlation between fungal biomass and $\beta$ glucuronidase activity in infections of Arabidopsis thaliana with transgenic Alternariabrassicicola. Plant Sci. 148, 1999, 31-36.

[46] Jung, H. W., and Hwang, B. K, Pepper gene encoding a basic $\beta-1,3-$ glucanase is differentially expressed in pepper tissues upon pathogen infection and ethephon or methyl jasmonate treatment. Plant Sci. 156, 2000,23-34.

[47] Jung, H. W., Kim, W., and Hwang, B. K, Three pathogen-inducible genes encoding lipid transfer protein from pepper are differentially activated by pathogens, abiotic, and environmental stresses. Plant Cell Environ. 26, 2003,915-928.

[48] Shin, R., Lee, G. J., Park, C. J., Kim, T. Y., You, J. S., Nam, Y. W., and Paek, K. H, Isolation of pepper mRNAs differentially expressed during the hypersensitive response to tobacco mosaic virus and characterization of a proteinase inhibitor gene. Plant Sci. $161,2001,727-737$.

\section{List of figures}




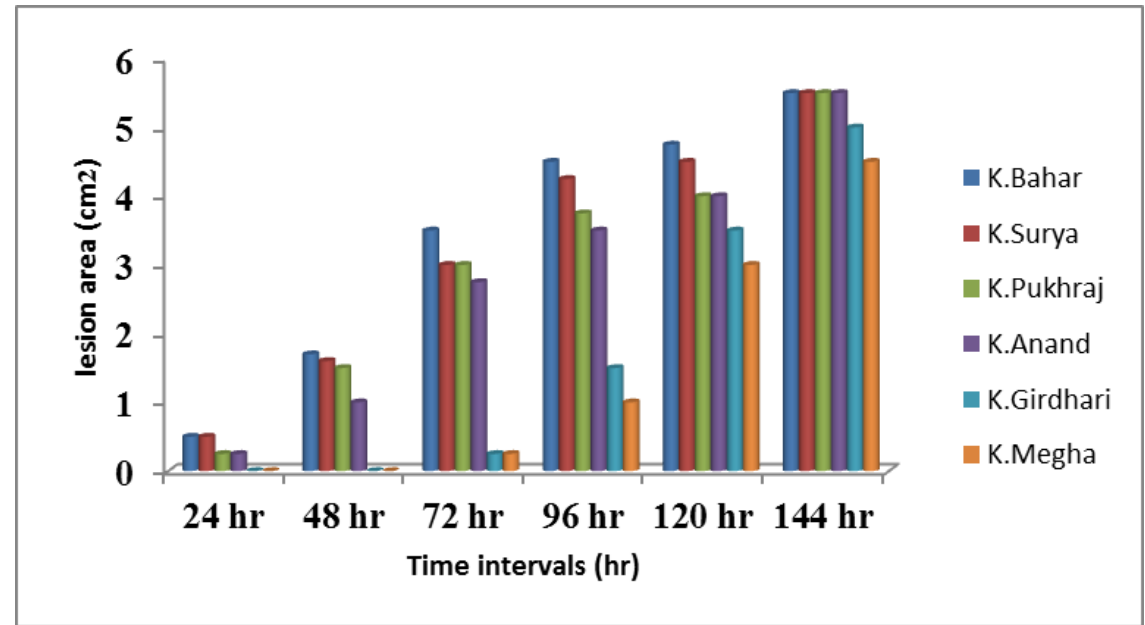

Fig.1. Phytophthorainfestansprogressive lesion area in leaves of different potato cultivars inoculated with HP-IS389 isolate.

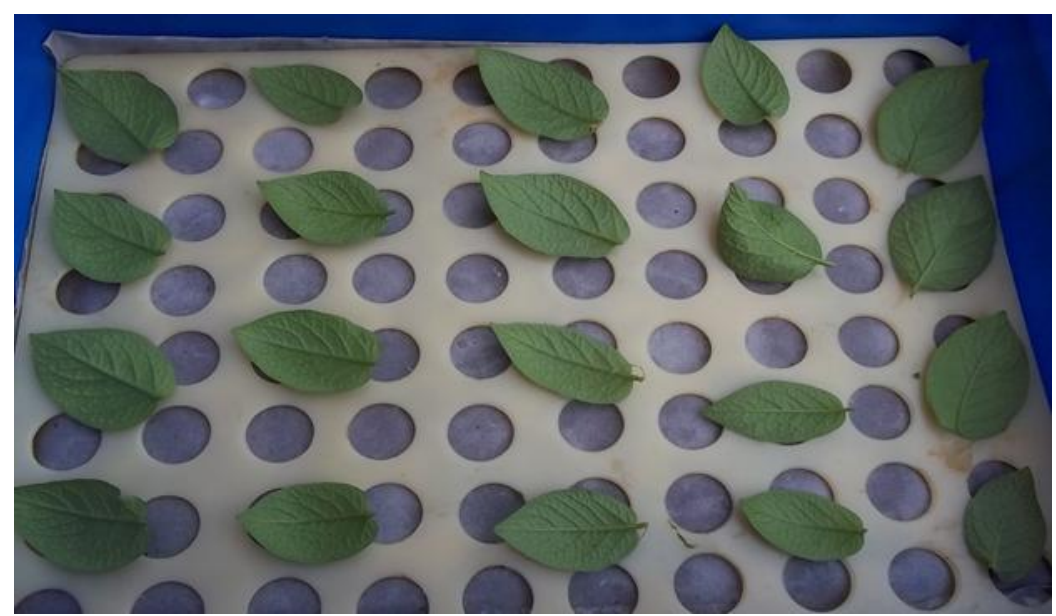

Fig. 2. Detached leaves study of k.bahar leaves at $24 \mathrm{hr}$ post inoculation.

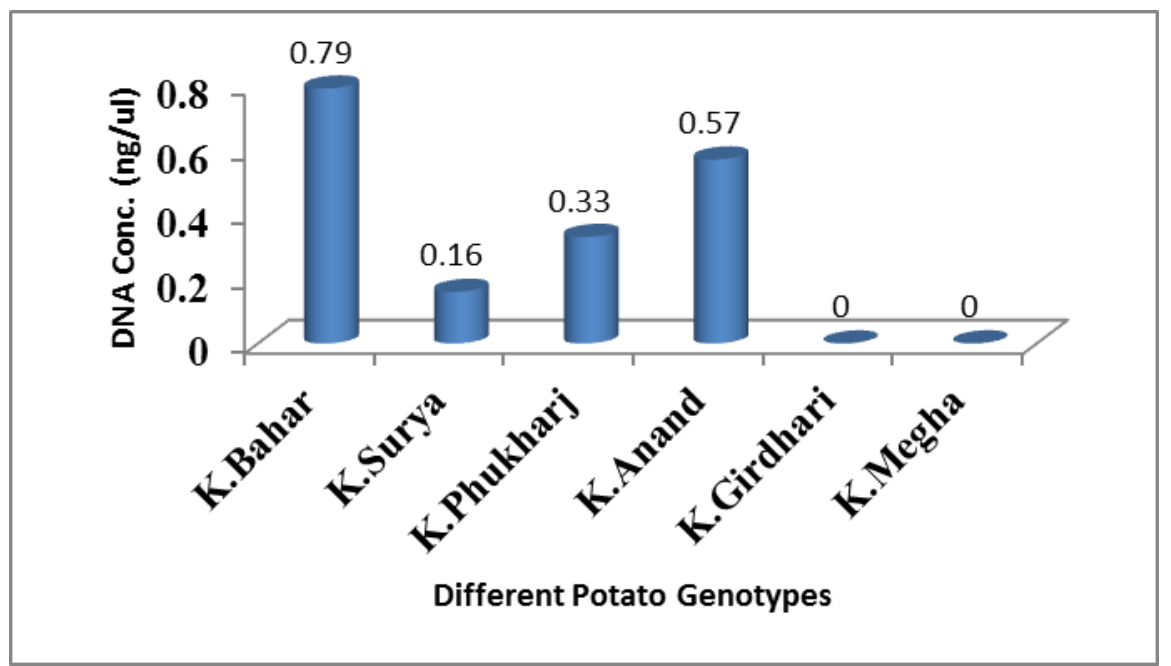

Fig.3. PhytophthorainfestansDNA (load) quantification in leaves of different potato cultivars at $24 \mathrm{hr}$ post inoculation. 


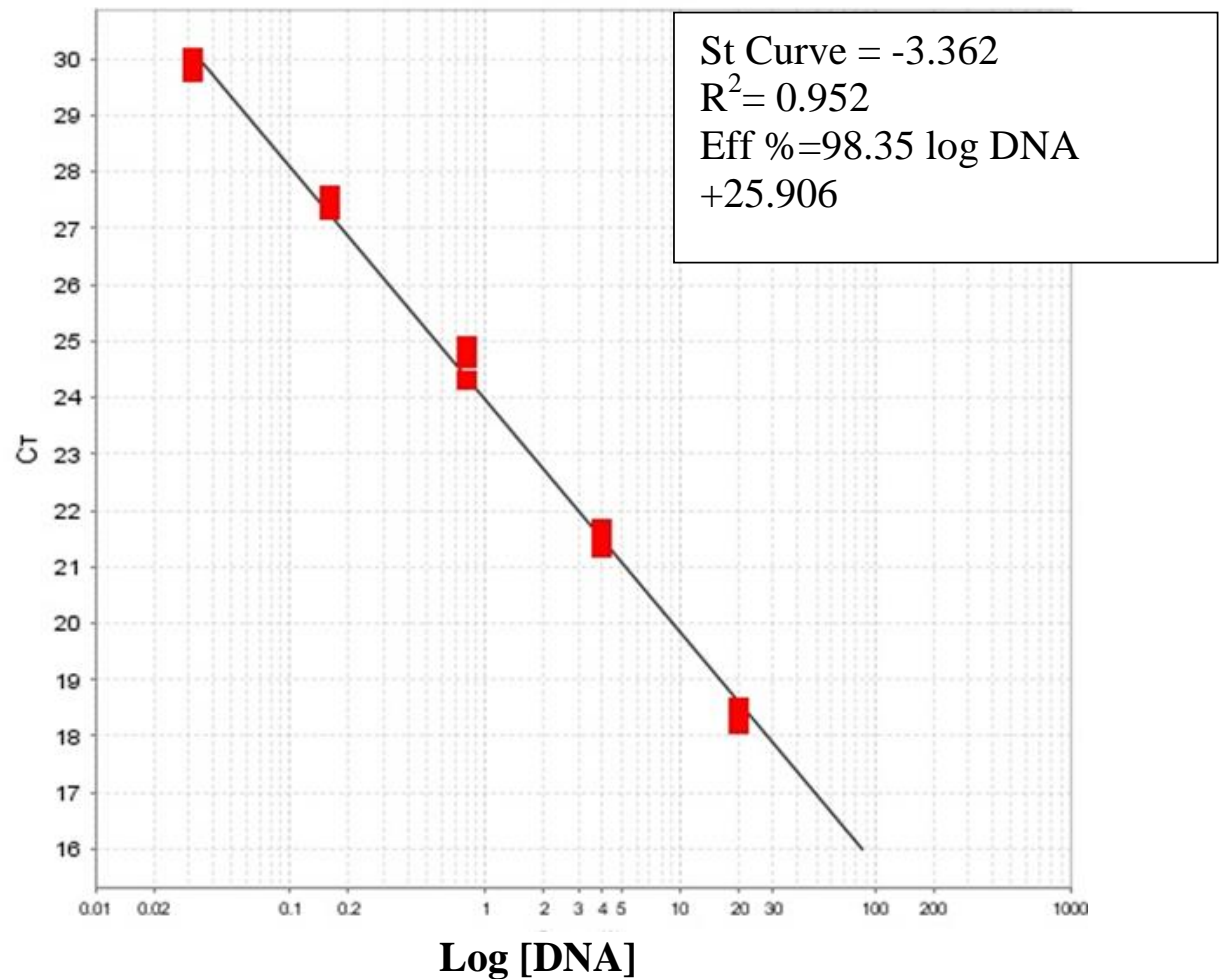

Fig.4. standard curves based on dilution of PhytophthorainfestansgenomicDNA for SYBR green dye assays targeting internal transcribed spacer (ITS).plots represent cycle threshold (ct) versus the log of DNA concentration. $P$. infestansDNA was diluted from concentrations of $5 \mathrm{ng} / \mu \mathrm{l}$ to $0.0005 \mathrm{ng} / \mu \mathrm{l}$.

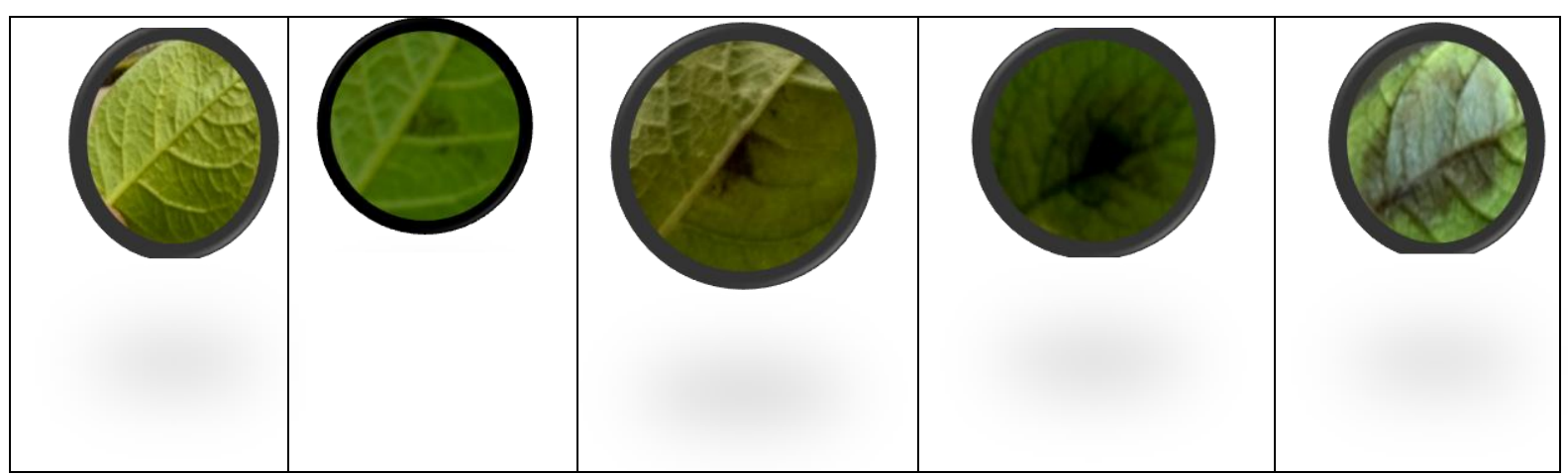

Fig.5.Diseases progression in potato leaf after inoculation of P.infestansinoculam, after every $24 \mathrm{hr}$ intervals.

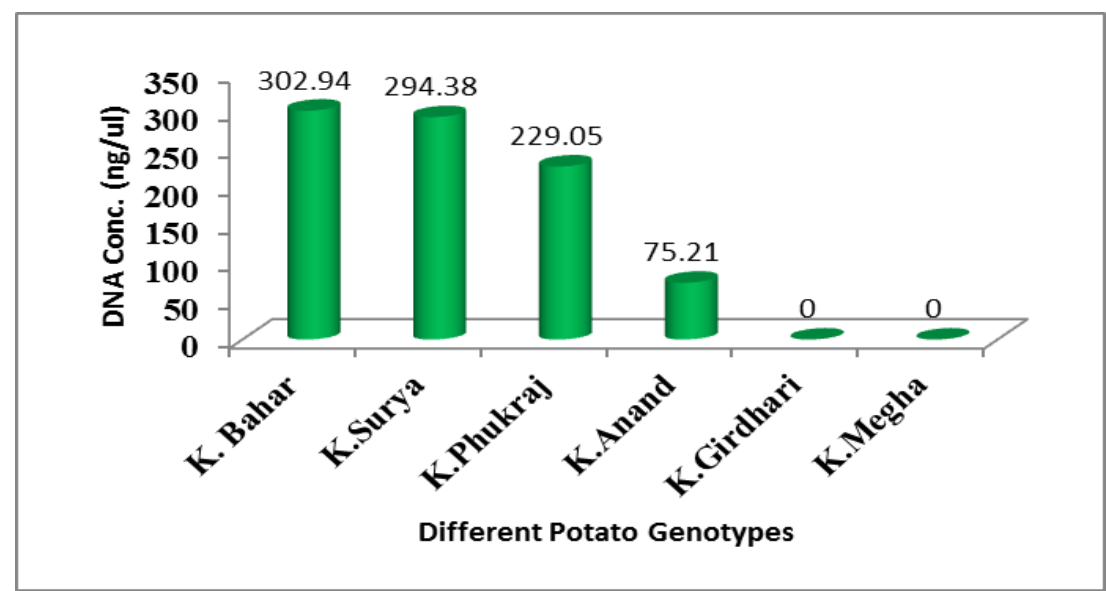

Fig 6.PhytophthorainfestansDNA (load) quantification in leaves of differentpotato cultivars at $48 \mathrm{hr}$ post inoculation. 


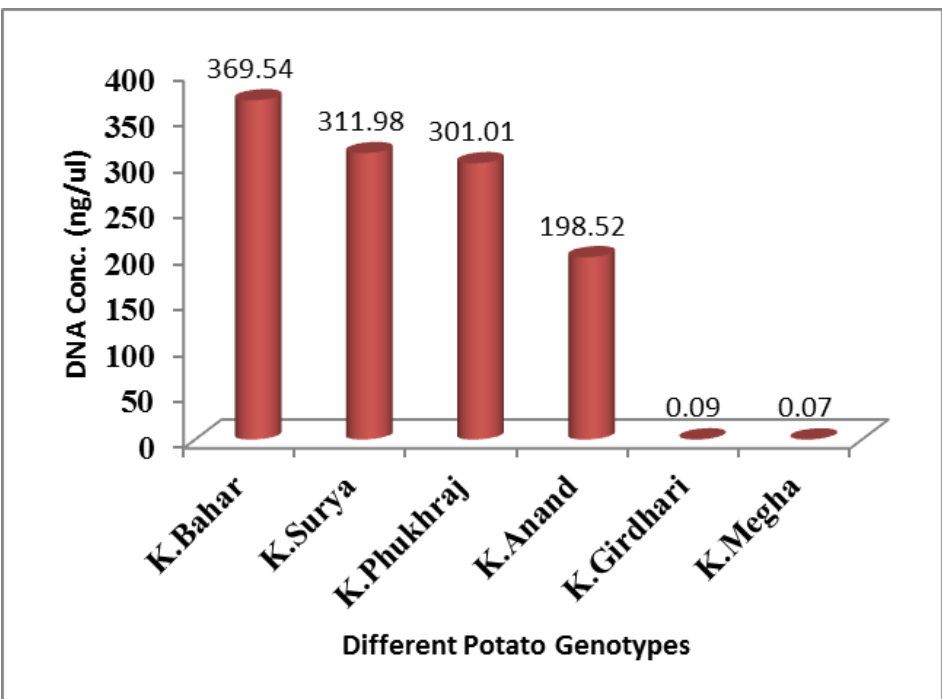

Fig.7.PhytophthorainfestansDNA (load) quantification in leaves of different potato Cultivars at $72 \mathrm{hr}$ post inoculation.

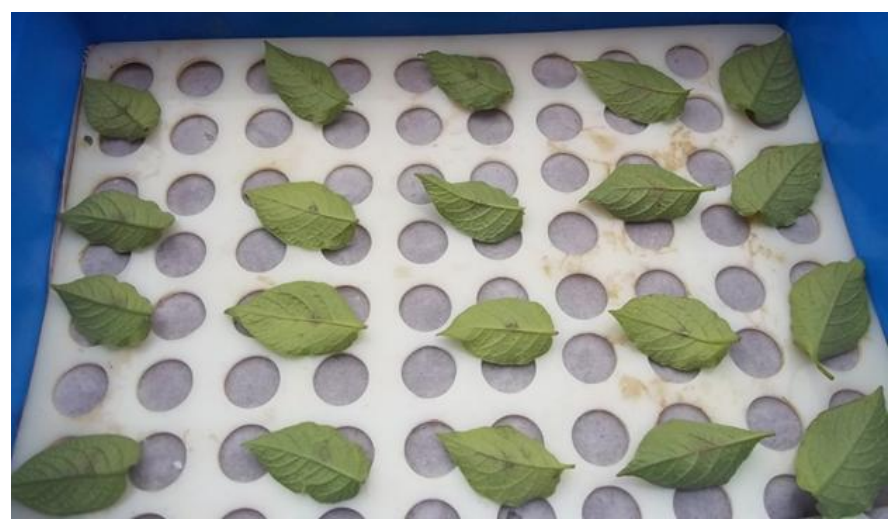

Fig.8. detached leaves study of cv. K.anand leaves at $72 \mathrm{hr}$ post inoculation.

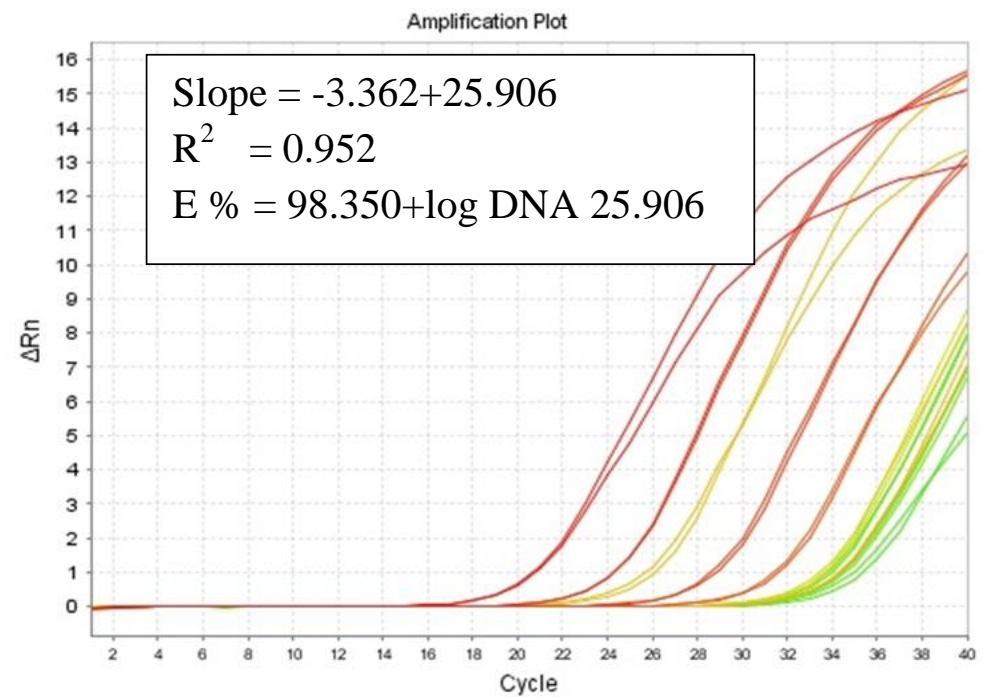

Fig.9. Amplification plot of artificially infected leaf at 24hr post inoculation. 